\title{
Tryptophan Content of the Serum Albumin of Normal and of Cadmium-Poisoned Monkeys
}

\author{
J. E. KENCH and ELIZABETH M. SUTHERLAND
}

From C.S.I.R. Protein Research Unit, Department of Chemical Pathology, University of Cape Town, South Africa

In order to characterize further the minialbumins (molecular weight 5,000 to 20,000 ) found in cadmiumpoisoned men and animals, the tryptophan content of albumins found in the serum and urine of cadmium-poisoned monkeys was measured by two methods and compared with that of serum albumin (molecular weight 66,000) of normal animals. Normal serum albumin of the monkey was found to contain 2 residues of trytophan per molecule of the protein, whereas all albumins in the poisoned monkeys, whether of normal size or low-molecular weight, contained less tryptophan, this amino acid being absent entirely in the minialbumins of both serum and urine. Serum albumin of the usual molecular weight $(66,000)$ in the cadmium-poisoned monkeys contained approximately $30 \%$ less tryptophan than its normal counterpart in untreated animals.

Taken in conjunction with previous observations on the behaviour of minialbumins, which aggregate readily in low-salt media including isotonic saline, it is concluded that approximately $30 \%$ of the circulating serum albumin in the poisoned monkeys arose by aggregation of minialbumin molecules. On the basis of the close similarity in amino acid composition, in nearly all other respects, between the various albumins, it is suggested that minialbumin comprises a mixture of peptides derived by fission of the normal albumin molecule along its whole chain length, and that subsequently a peptide containing both tryptophan residues is either deleted metabolically or excluded in the preparation procedures.

In recent publications (Kench, Gain, and Sutherland, 1965; Kench and Sutherland, 1966), we have described an abnormal albumin-and termed it minialbumin-isolated from both the urine and serum of men and animals chronically poisoned with cadmium chloride. We have suggested that this low-molecular weight albumin comprises a mixture of polypeptides, ranging in molecular weight from 5,000 to 20,000 , which is formed by fragmentation of the normal albumin molecule (Kench and Sutherland, 1966), which has a molecular weight of 66,000 . On Ouchterlony plates, minialbumins exhibit antigenic identity with albumins of normal molecular weight.

The amino acid composition of minialbumin is closely similar to that of normal albumin, the only significant differences we have observed in previous work being less lysine and cystine in the smaller protein. As normal albumin consists of a single chain containing approximately 575 amino acid residues (Potgieter, Hines, and Kench, in preparation) and only one or two residues of tryptophan, this comparative study of the tryptophan content of the two albumin species was carried out in order to seek further clarification of the relationship between them.

\section{Experimental and Results}

Preparation of Proteins Albumins were separated from the serum and urine of normal and cadmium-poisoned monkeys, as already described (Kench and Sutherland, 1966), either by the trichloracetic acid-acetone method of VallanceOwen, Dennes, and Campbell (1958) or by the hydrochloric acid-ethanol method of Fernandez, Sobel, and Goldenberg (1966). The albumins were subsequently fractionated, on a molecular weight basis, by filtration through cross-linked dextran gel $^{1}$. The gel was prepared, in $0.066 \mathrm{M}$ phosphate buffer, $\mathrm{pH} 7 \cdot 0$, containing $0.2 \mathrm{M}$ sodium chloride, as a column $42 \mathrm{~cm}$. long and $\mathrm{r} .8 \mathrm{~cm}$. in diameter. The column was run at $15 \mathrm{ml}$. per hour and the eluate was monitored at $262 \mathrm{~m} \mu$ through an ultraviolet 
absorptiometer ${ }^{1}$ with automatic recording of the optical density. Albumin of normal molecular weight emerged from the column ahead of minialbumin and well separated from it. The degree of purity was characterized by immunoelectrophoresis (Grabar and Williams, I955) against polyvalent antisera, and preparations showing only one precipitin band were used.

$\gamma$-Globulin was prepared from normal human serum by initial precipitation with ammonium sulphate and subsequent fractionation on DEAE Sephadex (Baumstark, Laffin, and Bardawil, 1964).

Methods of Analysis for Tryptophan Alkaline hydrolysis of the proteins with barium hydroxide was carried out by a modified version of the procedure of Noltmann, Mahowald, and Kuby (1962). The sample, usually ro mg. protein, was weighed into specially cleaned tubes and dissolved in approximately I ml. of distilled water. Solid $\mathrm{Ba}(\mathrm{OH})_{2} \cdot 8 \mathrm{H}_{2} \mathrm{O}$ and distilled water were then added to give a final concentration of $\mathrm{I}-2 \mathrm{~N} \mathrm{Ba}(\mathrm{OH})_{2} \cdot 8 \mathrm{H}_{2} \mathrm{O}$ in a calculated final volume of $0.2 \mathrm{ml} . / \mathrm{mg}$. protein ${ }^{2}$. The tubes were then alternately evacuated and flushed with nitrogen until all traces of air had been removed and were subsequently sealed under vacuum. Hydrolysis was allowed to proceed at $110^{\circ} \mathrm{C}$. for 70 hours, at which time the seal was opened and the tube's contents were transferred quantitatively with hot distilled water to a centrifuge tube. A stream of carbon dioxide, liberated from solid $\mathrm{CO}_{2}$, was directed onto the surface of the sample whilst it was shaken continuously for Io minutes. The precipitate of $\mathrm{BaCO}_{3}$ so obtained was centrifuged off and washed three times with distilled water. The initial supernatant and the washings were filtered through a medium sintre and then lyophilized. The dried amino acids were dissolved in $5 \mathrm{ml}$. of $0.2 \mathrm{M}$ sodium citrate buffer, pH 2.2, and analysed on a Beckman Spinco Model I $20 \mathrm{~B}$ amino-acid analyser, according to the method of Spackman, Stein, and Moore (1958).

Tryptophan and leucine are the only amino acids present in the proteins which undergo no degradation under the conditions of alkaline hydrolysis as just described. Leucine, unlike tryptophan, is also stable during acid hydrolysis and can, therefore,

\footnotetext{
'LKB Uvicord.

${ }^{2} 4 \mathrm{~N} \mathrm{Ba}(\mathrm{OH})_{2}$, the concentration advocated by Noltmann and his colleagues (1962), was found to give rise to severe loss of tryptophan, particularly during hydrolysis of $\gamma$-globulins, and the recoveries of leucine were also impaired. The optimal concentration of $\mathrm{Ba}(\mathrm{OH})_{2}$ for analysis of albumin was established at IN for normal albumin and at $2 \mathrm{~N}$ for albumin hydrolysed in the presence of cadmium (I $\mu \mathrm{g} . \mathrm{Cd} / 5 \mathrm{mg}$. protein).
}

serve as a reference standard by which tryptophan can be related to the other amino acids, all of which can be measured with the automatic amino acid analyser following acid hydrolysis of the protein. The height-width constants for leucine were determined after both acid and alkaline hydrolysis, and, by use of these constants, the quantities of all the amino acids in the alkaline hydrolysate could be calculated. From these data the content of tryptophan as a percentage of total protein was easily derived.

Tryptophan was also determined by the method of Spies and Chambers (1948, 1949) in which either the free or protein-bound tryptophan was treated with $p$-dimethylaminobenzaldehyde (DMAB) in sulphuric acid before development of colour by oxidation with sodium nitrite. By employing I9N $\mathrm{H}_{2} \mathrm{SO}_{4}$ and $30 \mathrm{mg}$. p-dimethylaminobenzaldehyde and an incubation period of 12 to 15 hours, a maximum initial reaction was ensured, whilst subsequent addition of $0.1 \mathrm{ml} .0 .045 \%$ $\mathrm{NaNO}_{2}$ gave maximum colour yield after 30 minutes. The blue-coloured product was stable for two to three hours and had an absorption peak at $580 \mathrm{~m} \mu$. The whole process was conducted in the dark. Five to Io milligram samples of protein were analysed and the tryptophan content was determined by reference to standard curves prepared using free tryptophan (Figure). Reagents were Analar grade,

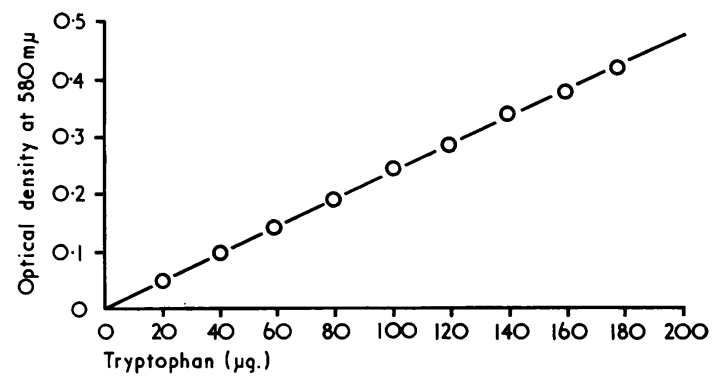

FIGURE. Standard graph obtained using free tryptophan with the colour reaction method.

and only freshly-prepared solutions were used. Reagent blanks containing all the reagents, except $p$-dimethylaminobenzaldehyde, and protein blanks containing all the reagents but read at $0 \mathrm{~min}$. were run concurrently.

The analytical procedures for tryptophan were checked by measurements on $\gamma$-globulins-proteins, rich in tryptophan, in which the number of residues present is well established. The alkaline hydrolysis method gave $91 \cdot 5 \pm 3 \cdot 1 \%$ (S.D., $n=5$ ) of theory 
while the DMAB colour method gave $95 \cdot 6 \pm 4 \cdot 1 \%$ (S.D., $n=6$ ). The mean percentage recovery of free tryptophan added to normal monkey albumin was $83.2 \pm I \cdot 9(n=3)$. In order to ascertain whether free tryptophan present in the serum might become adsorbed on albumin during the preparative procedure, and perhaps thereby vitiate the observations, varying quantities of tryptophan were added to the serum before albumin was prepared from it. As shown in Table I, added tryptophan had no significant effect on the quantity of the amino acid found in the protein.

\section{TABLE I}

\begin{tabular}{c|c}
\hline $\begin{array}{c}\text { Tryptophan Added } \\
\text { (moles per mole albumin) }\end{array}$ & $\begin{array}{c}\text { Tryptophan Found } \\
\text { (residues per mole albumin) }\end{array}$ \\
\hline O & 0.91 \\
I & 0.93 \\
2 & 0.91 \\
3 & 0.95 \\
\hline
\end{tabular}

This experiment was made on poisoned-monkey serum using the DMAB colour method of measurement.

The direct effect of cadmium on the analysis was studied by addition of cadmium chloride to the serum of a normal monkey before albumin preparation, in the concentration that is found in a monkey immediately following intravenous injection of $6 \mathrm{mg}$. cadmium (i.e., $24 \mu \mathrm{g}$. cadmium $/ \mathrm{ml}$. serum). Measurements were made by the DMAB method. The results are presented in Table II.

\section{TABLE II}

\begin{tabular}{|c|c|}
\hline Sample & $\begin{array}{c}\text { Tryptophan Residues } \\
\text { per mole }\end{array}$ \\
\hline $\begin{array}{l}\text { Normal monkey serum albumin } \\
\text { Normal monkey serum albumin } \\
\text { with added cadmium }\end{array}$ & $\begin{array}{l}I \cdot 73, I \cdot 78 \\
I \cdot 7 I, I \cdot 65\end{array}$ \\
\hline
\end{tabular}

It is evident that cadmium ions have no direct effect on the analytical procedure.

The numbers of tryptophan residues in the various albumins, as determined by both analytical procedures, are given in Table III.

\section{Discussion}

From the results obtained, it appears that normal monkey albumin contains two residues of trypto-
TABLE III

\begin{tabular}{l|c|c}
\hline Type of Albumin & $\begin{array}{c}\text { Tryptophan } \\
\text { Residues } \\
\text { per mole } \\
\text { (alkaline } \\
\text { hydrolysis)* }\end{array}$ & $\begin{array}{c}\text { Tryptophan } \\
\text { Residues } \\
\text { per mole } \\
\text { (DMAB } \\
\text { colour } \\
\text { method)* }\end{array}$ \\
\hline $\begin{array}{c}\text { Normal monkey serum } \\
\text { normal albumin }\end{array}$ & 2.11 & 1.95 \\
$\begin{array}{c}\text { Poisoned monkey serum } \\
\text { normal albumin }\end{array}$ & 1.32 & 0.97 \\
$\begin{array}{c}\text { Poisoned monkey serum } \\
\text { minialbumin }\end{array}$ & 0.00 & 0.00 \\
$\begin{array}{c}\text { Poisoned monkey urinary } \\
\text { normal albumin }\end{array}$ & 1.65 & 1.69 \\
$\begin{array}{c}\text { Poisoned monkey urinary } \\
\text { minialbumin }\end{array}$ & 0.00 & 0.00 \\
\hline
\end{tabular}

*Each value is the mean of three to six determinations on three normal or on three poisoned monkeys and is corrected for recoveries, already described.

Normal and mini refer to molecular weight only-all the albumins prepared from cadmium-poisoned monkeys are abnormal in their content of tryptophan.

phan per molecule of albumin. Bovine serum albumin (Ramachandran and Witkop, 1959) and canine plasma albumin (Tristram and Smith, 1963) have likewise been shown to contain two residues per mole, but there is still controversy as to whether there are one (Ramachandran and Witkop, 1959; Spahr and Edsall, 1964) or two residues (Beaven and Holiday, 1952) of tryptophan per mole in human albumin.

Both the tryptophan residues are missing from the minialbumins of serum and urine. It is possible that the lost tryptophan is linked to cystine and lysine (amino acids consistently less in minialbumins) in a peptide which was metabolically dissociated from the remainder of the normal albumin molecule under the influence of cadmium ions, or that such a peptide was accidentally discarded during minialbumin preparation. The tryptophan-containing moiety appears to be irreversibly lost since aggregation of minialbumin, which has been observed to occur in low salt concentrations (Kench and Sutherland, 1966), leads to a large-size molecule containing less tryptophan than does albumin from a normal animal. This aggregation seems to be partially reversible, and an equilibrium between small and large molecules apparently exists. This phenomenon may explain the lower tryptophan content of albumins of normal molecular weight prepared from sera and urine of poisoned monkeys. The albumin of normal molecular weight in the serum of poisoned monkeys appears to be a mixture of approximately equal numbers of normal molecules and of molecules formed by aggregation 
of minialbumin. The corresponding urinary albumin of these animals appears to contain fewer molecules (approximately 13\%) which are aggregates. Minialbumins found in urine do not aggregate so readily as those in the serum, but this difference in behaviour seems inexplicable at present, although we have preliminary evidence that urea, in the concentrations to be found in urine, may inhibit aggregation. Cadmium ions have a profound effect on albumin metabolism. Whatever the underlying biochemical changes may be, 40 to $60 \%$ of the albumin molecules circulating in the serum of cadmium-poisoned animals are abnormal in amino acid composition, molecular weight (Kench and Sutherland, 1966) or in both. Since minialbumins so far studied by Ouchterlony (1962) techniques all give the reaction of identity with albumins of normal molecular weight, when run against antisera prepared against the latter, it is clear that, as far as the precipitin reaction is concerned, antigenic sites in the various albumins do not include the tryptophan residues nor the segment or segments of the molecule, rich in lysine and cystine, in which tryptophan may be located. This work is continuing, our aim being, by more detailed analytical study, to characterize the minialbumins more thoroughly and thereby to define more precisely the biochemical lesions induced by cadmium ions.
We wish to thank our colleagues, Drs. G. M. Potgieter and M. C. Berman, for valuable discussions and advice. Miss Elizabeth Hall kindly performed the analyses on the Beckman Spinco amino acid analyser Model I2OB, which was purchased by means of a special grant from the C.S.I.R.

\section{REFERENCES}

Baumstark, J. S., Laffin, R. J., and Bardawil, W. A. (1964). Arch. Biochem., r08, 515.

Beaven, G. H., and Holiday, E. R. (1952). In Advances in Protein Chemistry, 7, 319.

Fernandez, A., Sobel, C., and Goldenberg, H. (1966). Clin. Chem., 12, 194.

Grabar, P., and Williams, C. A., Jr. (1955). Biochim. biophys. Acta (Amst.), 17, 67.

Kench, J. E., Gain, A. C., and Sutherland, E. M. (1965). S. Afr. med. F., 39, II91.

$\longrightarrow$, and Sutherland, E. M. (1966). Ibid., 40, 1109.

Noltmann, E. A., Mahowald, T. A., and Kuby, S. A. (1962). f. biol. Chem., 237, II46.

Ouchterlony, O. (1962). Progr. Allergy, 6, 30.

Ramachandran, L. K., and Witkop, B. (1959). F. Amer. chem. Soc., $81,4028$.

Spackman, D. H., Stein, W. H., and Moore, S. (1958). Analyt. Chem., 30, I 190.

Spahr, P. F., and Edsall, J. T. (1964). F. biol. Chem., 239, 850. Spies, J. R., and Chambers, D. C. (I948). Ibid., 20, 30.

, and (1949). Ibid., 21, 1249.

Tristram, G. R., and Smith, R. H. (1963). In Advances in Protein Chemistry, 18, 227.

Vallance-Owen, J., Dennes, E., and Campbell, P. N. (1958). Lancet, 2, 336. 